\title{
Identity, remembrance and transformation as key concepts in biblical hermeneutics
}

\author{
Kari Syreeni \\ Department of New Testament Studies \\ University of Uppsala \\ UPPSALA \\ SWEDEN \\ E-mail: kari.syreeni@teol.uu.se
}

\begin{abstract}
Identity, remembrance and transformation as key concepts in biblical hermeneutics
\end{abstract}

The concepts identity, remembrance and transformation are discussed in this article to highlight the dialectic of historical change. Identity as a basic concept falls in the hermeneutical middle ground between theology ("truth") and politics ("power"). Identity pertinently denotes the symbolic construction of a living person or a social group, but identity is also applicable to other entities. Identity involves difference and relatedness, "inside" and "outside" aspects of understanding, as well as processes of objectivation (subjectmaking) and attribution (conceptual enrichment). Historically, identity can be defined as the memory of its attributions. Historical identities only remain the same through continually renewed remembrance and transformation. In the course of the discussion, this basic theory is applied to biblical hermeneutics. The underlying practical issue concerns women's role in church and society.

I wish to express my sincere thanks to Prof. Fika J. van Rensburg for inviting me to participate in this ground-breaking project on women in church and society. ${ }^{1}$ The practical aim of the project is to further women's role, especially in the service of the Church. To that end, both thorough historical research and a quest for proper scriptural interpretation are called for. Hermeneutics is a historical and contextual enterprise, so the first question I posed to myself was how an outsider Scandinavian white male academic scholar, coming from a rather

1 The present article is a slightly modified version of a paper read at the first Potchefstroom workshop on "Women in Church and Society" on May 4, 2001. 
homogeneous cultural and religious milieu, and with roots in the Lutheran tradition - might best contribute to a South African project. Obviously I must come as I am, an outsider, although not an objective outsider, for we all carry with us a heavy package of scholarly, cultural and religious traditions.

Understanding and interpretation are, in my opinion, thoroughly human matters. Biblical hermeneutics, too, is a human effort to interpret and apply historical documents in certain historical and cultural circumstances. On a more theoretical level, it involves the study of the methodological and ideological presuppositions of interpretation, as well as the study of possible, legitimate and actual interpretations. All interpretation should be critical and self-reflective, and some basic elements of this (self-)critical awareness are common to all forms of understanding, irrespective of time, place and cultural differences. The context of interpretation does, however, affect the priority of goals, means and criteria. In an academic setting, the priorities include that the interpreter be informed of the methods and results (or hypotheses) of biblical exegesis, and that the interpreter be primarily responsible for doing justice to the study object and respecting the intellectual values of the scholarly community. A church context, or a particular social and political situation, may call for other legitimate priorities. Mostly the contexts in which we interpret the Bible are complex, so that academic, social, political and religious goals, methods and criteria are intertwined. It cannot be otherwise; everything we do, we do as whole persons and social beings.

As I understand the present context, it is primarily academic when it comes to scholarly methods and the presupposed store of knowledge, but includes the specific moral obligation to further social and religious justice in gender-related issues in a South African setting. This moral goal should direct and inform the common project, but not overshadow our scholarly responsibilities. Keeping this in mind, I will discuss some basic hermeneutical concepts, applying these to biblical hermeneutics in general as well as to the particular interests of the project.

The general framework that underlies my conception of biblical (or any other) hermeneutics is the model of three worlds. ${ }^{2}$ The "worlds" are, of course, not those of Western political discourse, but analytical and phenomenal levels of reality. "Text world" stands for linguistically created meaningful entities. "Symbolic world (/universe)" denotes the realm of

2 For a short introduction, see Syreeni (1999). The hermeneutical three-world model is in part rooted in Berger and Luckmann's sociology of knowledge and presupposes a constructionist basic approach. 
individual, social and cultural interpretative-behavioural systems (values and schemes). "Concrete world" is the compelling material (physical, chemical) reality around us. When reading, we enter a text world; when thinking, feeling and making plans for the future, our primary level of action is symbolic; and when hungry, we concretely need food.

From this perspective, it is clear from the outset that hermeneutics does not only concern scriptural interpretation; it is just as much about our understanding of life. Why, then, did I choose precisely identity, remembrance and transformation from the multitude of basic hermeneutical concepts? My thesis is that these concepts belong together and are the key to understanding the dialectic of historical continuity and change. If you substitute remembrance for tradition, and transformation for the reinterpretation of tradition in a new situation, you arrive at the familiar historical-critical discourse on "tradition and redaction". The dialectic between tradition, experience and re-interpretation also forms the basis of my teacher, Prof. Heikki Räisänen's, hermeneutical model (Räisänen, 2000:189-202). By introducing identity as the initial issue, by defining tradition more closely as a memory of the past, and by widening the concept of (re-) interpretation to encompass transformation on all levels of reality, I am both drawing from and modifying Räisänen's model. ${ }^{3}$

\section{Identity - between truth and power}

\subsection{Why begin with identity?}

To start with the concept of identity is a crucial theoretical choice, as a comparison with two alternative foundations shows. We might begin with the concept of truth, as some neo-orthodox discourse and a recent book on New Testament theology by Christof Landmesser (1999) 4 recommend. We might also consider power the most basic concept, as suggested in our time by the French philosopher Michel Foucault and several feminist scholars. Both are legitimate approaches, but I fear that the former too easily bends hermeneutics towards normative theology, while the latter tends to turn it into politics or rhetoric. Truth and power

3 In Räisänen's model, historical interpretation and contemporizing are clearly distinguished according to a two-level strategy (Räisänen, 2000:203-209). While the idea of two levels is more adequate than the old historical-critical idea of two stages, Räisänen"s distinction may (but need not) divorce the two foci of interpretation too strongly. As I begin with identity, I am looking for a basis for a general theory of historical understanding, in which contemporary interpretation is included.

4 Landmesser, 1999. See my review of Landmesser's book in Journal of Biblical Literature 119 (2000):347-349. 
are certainly important issues, but identity as a starting-point falls more safely in the middle ground between theology and politics. 5

Identity is the relatively stable, but not unchanging vantage point, from which a historical process, an artefact, a social group or an individual's life is more or less formed to what it "is", or more precisely, how it perceives itself and is perceived by others. It is typically but not exclusively a psychologically and socially interpreted reality, thus mainly belonging to the symbolic world. While we also "identify" physical and artefactual entities ${ }^{6}$, identity in its most immediate and obvious sense denotes the symbolic construction of a living person. I am "me", an identity. Note this broad and wholistic definition: I not only "have" but really am an identity on the symbolic level of reality, just as - in the concrete world - I am my body, I do not just "have" it. Of course, identity also involves attributes that I "have". I have a (textual) name; I have defined myself (ideologically) as a Scandinavian male scholar; (concretely) I was born in Helsinki in 1952. However, I have not always been what I am. At first I had no name, and the one I received was initially not my but my parents' and outsiders' name for "me". My identity is to a great extent a social construction; others have contributed to what "I" am. I have become a subject; yet through me, others - my parents, teachers, loved ones and friends, even those I dislike - indirectly speak and act. Some elements of my identity were given to me at birth; the genes come from my physical parents. Other elements were more or less given by my social milieu, such as the basic lower-middle-class view of gender roles and societal power relations. Only some elements are my own choices, but I like to think, rightly or wrongly, that these are the decisive formative factors of my identity.

5 Yet another starting-point might have been life. Being both a classical concept in general hermeneutics (cultural artefacts as life utterances) and a prominent concept in biblical hermeneutics, the concept of life might be a feasible point of departure (cf. Berger, 1988:21-22). I only fear that the naturalistic, often Darwinistic view of life (the survival of the fittest) and the biblical view (eternal life, resurrection) are too remote to allow for a mediating, hermeneutical definition. Yet for practical purposes, identity - in the very broad and abstract hermeneutical sense as I define it below - is almost equivalent to "life". Interestingly, identity is also one of Berger's basic criteria (Berger, 1988:48-50).

6 Entity is an object before or apart from its recognition as an identity, i.e., a conglomeration of concrete, symbolic and/or artefactual features which are the "raw material" for identity construction. An object remains an entity in so far as it is not identified, defined, and treated as a hermeneutical subject. Thus, the physical object on which I am sitting is an entity but becomes a rudimentary identity when I identify it as "a chair", or define it more closely as "the blue chair in my office". It may on occasion receive a fuller (i.e., more conceptually enriched) symbolic and artefactual identity, as when I think of it as "my welldesigned blue office chair that stands vacant, symbolising my absence and leisure time, patiently and mildly rebuking me and waiting for my coming to work". What remains the same, irrespective of my various definitions, is the chair as a concrete-world entity. 


\subsection{Identity as difference and relatedness}

My identity, then, is a complex matter, shaped by the concrete physical and historical world, my social and cultural milieu, and my deliberate choices. I recognise myself as an individual subject, yet am shaped by other people. From my earliest years, I have only learned to understand myself as "me" in relation to Others, those outside my direct control and power. I know my identity from within, and other identities from outside, even though there are degrees of knowledge involved. This hermeneutical difference between the inside and the outside is given with, and is the price of, identity. At the same time, all identities with their inside and outside spheres are related to one another.

Being differential and relational, the construction of identity involves both separating and uniting hermeneutical procedures. Religion, one of the most fundamental hallmarks of humanity, is deeply present in both cases. The separating effect of identity asserts itself, among other things, in the basic religious distinction between the sacred, the profane and the unholy (sinful or polluted) spheres of reality. In the ancient Israelite religion, specific holy sites, times and people were separated for the service of God. Food was divided into holy (offerings to God), profane (ordinary eatable food) and unholy (forbidden). Even in the modern secularised world, Christians, too, recognise such demarcation lines and experience the presence of the sacred. While the separating aspect of identity involves boundaries, the uniting aspect assumes bonds of affinity.

\subsection{The power of naming}

The difference between the subjective or inside aspect of identity on the one hand, and the objective or outside aspect on the other is the root of all subsequent problems with identity. Thus, the question of true identity is intertwined with the power to define objects from the inside and from the outside. On the surface, this power seems a property of language. I define objects in my surroundings according to my language competence and differential subjectivity. Language unites us by giving us common terms and concepts, but it also exposes our subjectivity in the way we understand and use them. Language suggests ready-to-use names for things that could be defined otherwise. At the same time, it enables us to rename and redefine things. In an article on gender and discipleship in Matthew's passion narrative, Talvikki Mattila rightly points out that naming is a crucial form of exercising power. She remarks that only the twelve male apostles are called disciples in Matthew, although many women followers of Jesus had the same narrative functions, often being more worthy followers than the disciples (see Mattila, 1999). While it is 
true that a disciple of Jesus is a male person in Matthew, this truth uncovers a power relation: disciples are thus named and defined by Matthew, and through him, indirectly by his male-dominated, patriarchal culture. According to Mattila, this observation challenges women to begin the process of creating a new language so that they can speak out their own reality. The more general issue here is the discrepancy between the inner and outer definition of identity. An object that has become a subject demands a hearing for its inside understanding of itself. Up to a certain point, we wish to be understood by others as we understand ourselves. If others' language is not ours, we may create our own words and definitions in the hope that these may be accepted by others as our true definition.

However, language is not all reality. There is no difference between him and her in my native language, Finnish. All the personal pronouns are the same for these two grammatical genders. Of course, I noticed early on that in the real world there are different sexes. I also found that there were specific social roles for the two sexes, man and woman, which defined them as two different (symbolic) genders, male and female. ${ }^{7}$ As a child I took such roles for granted; there are certain things that men do and women do not do. I never wondered why all ministers in the Finnish Church were men, or why so few women occupied a prominent place in society. In my adult years, I learned that gender roles are subject to change just like any other elements of identity; there are now female ministers in practically every local community of the Church, and the President of Finland is a woman.

\subsection{Primary and secondary hermeneutics}

Differential subjectivity also constitutes the distinction between primary and secondary hermeneutics. The subject matter of primary hermeneutics is myself and my understanding of reality. For you, the subject matter is your understanding of reality. But how can we understand others? This is the subject matter of secondary hermeneutics - a vast area including, among many other things, biblical exegesis. Exegesis is about people, events, interpretations and documents from some two thousand years ago. That such matters might concern our identity is something that has

In recent feminist discourse, sex and gender are often discarded as separate categories. However, discriminately used, the distinction is useful and corresponds to the difference between concrete and symbolic reality. In addition, the three-world model suggests that we distinguish artefactual (or more precisely, expressive) aspects of sex/gender; these include the traits of gender-related ideology in one's self-expression (hair style, clothing, manner of speech, and so on). 
been related to us by other identities: parents, loved ones and friends, a faith community, the media, the Bible.

Primary hermeneutics engages me from within on all levels of reality. The only body I know from within is mine. The only complete ideology the total structure of intellectual, emotional and behavioural schemes - I really know is my way of understanding, interpreting and responding to reality. The cultural artefacts I know most intimately are those that I have produced or appropriated: the texts I have written, the clothes I wear to articulate my social appearance. Other bodies, ideologies, and artefacts I know by observing them and trying to infer their meaning, imagine how they must be felt and experienced. I understand things of my own primary sphere of existence to a greater extent than things outside that sphere. I listen to myself more closely, understand my motives more than I would do with others. Strangely, however, when I come close enough and my identity is at stake, I suddenly become hermeneutically blind and do not see my motives as clearly as I see yours: I rationalise, make excuses and pretend, although I am fully able to see similar biases in your behaviour (cf. Matt 7:3). Thus, primary hermeneutics is a privileged point of view, but at the same time it sets crucial limits to my understanding.

There is, however, no water-tight division between primary and secondary hermeneutics. I "know" some other bodies intimately enough; I have a wife and two sons. Some social, ideological and artefactual realities have become my significant others. For instance, my understanding of being in the world is much more informed by a Christian tradition and the Bible than by other religious traditions or documents. Yet there are degrees and variety; the New Testament seems more significant to me than the rest of the Bible, and some documents outside the canonical "family" seem as significant as those inside. ${ }^{8}$

The terms "primary" and "secondary" suggest that hermeneutics, in some qualified sense, is primarily about myself. However, if the starting-point and primary focus of hermeneutics is my identity, then obviously the goal and ultimate focus is the Other. To be sure, we cannot really set apart the two foci, but as far as we remain differential and relational subjects these focal points are not identical. We do not know the Other as we know ourselves. Paul believed that things will change after this life. "My knowledge now is partial: then it will be whole, like God's knowledge of me" (1 Cor. 13:12). Knowing the Other perfectly, and being perfectly known by the Other, would in effect abolish the difference between

8 Being a New Testament scholar is my own ideological choice and indicates that the Old Testament is somewhat farther away from my identity but still closer than a profane body of literature. 
primary and secondary hermeneutics, indeed it would render all hermeneutics obsolete. However, as Paul knew - and sometimes forgot - then is not now. Since we live now, we need hermeneutics.

\subsection{Bonds of affinity}

No man or woman is an island; as relational identities we are tied with various bonds of affinity. It is tempting even to speak of a bond of love, as in 1 Clem. 49:2, a passage developing Paul's teaching on the primacy of love (1 Cor. 13). The bonds that tie humans together are both intellectual and ethical. Complete "inside" knowledge of myself and the Other would eradicate any difference between what is inside and what is outside - an idea entertained not only by Paul but, in a more radical way, also by the early Christian Gnostics. An ethical variant of the idea of uniting the inside and the outside is articulated in the golden rule: Love your neighbour as yourself (Matt. 7:12). This is a prominent idea in both Old and New Testament ethics and might almost be regarded as the ethos of the Bible. However, in practice the burning question is: Who is my neighbour (Luke 10:36)? In the Old Testament, the neighbour was mostly, but not exclusively, a fellow Jew, so the bond of love was ideally established by a communality of faith, nation and culture, and to some extent by the idea of the holy land. In the New Testament, we see a radically new form of identity in formation, in which only the common faith counts. This may seem a universal bond of love, yet faith now becomes the demarcation. Paul's emphasis on brotherly love in 1 Thessalonians 4:9-12 indicates the borderline: "But concerning love of the brethren, you have no need to have any one write to you ... But we exhort you, brethren, to do so more and more, to aspire to live quietly, ... so that you may command the respect of outsiders ..." In John, the borderline is a huge gap: inside is the peace zone of Christian existence, outside is the hostile world (John 16:33). Even in the inside, there are degrees of love: "Simon, son of John, do you love me more than these?" (John 21:15).

According to Paul, "There is no longer Jew or Greek, there is no longer slave or free, there is no longer male and female; for all of you are one in Christ Jesus" (Gal. 3:28). This is a theological anticipation of the ultimate then. Hermeneutically speaking, Paul makes an effort to substitute one's actual differential identity for an ideal symbolic identity common to all believers. Christians are not just Christians, however: there are differences in terms of nationality, cultural background, life experiences, and we are still male or female. Identity means difference, and difference implies a complex relatedness, because we are united by many various bonds of affinity. Paul may well have made a good theological point, but hermeneutically his statement is not valid. 
I hope it is evident why I so keenly distinguish hermeneutics from both theology and rhetoric. At its most extreme, theology exceeds the limits of hermeneutics and enters into areas that are either beyond the farthest limit of this-worldly Others or so near to ourselves that we become hermeneutically blind. In Galatians 2:20, Paul passes both limits at once: "It is no longer I who live, but Christ who lives in me". This could be about the most powerful theological and rhetorical statement in the Bible, but hermeneutically I am unable to say whether it is also the most truthful one. Paul takes the farthest Outsider, one who is unlike any human being, as his own Self, and thus in effect he denies his differential identity". Nevertheless, the ethical dilemma is obvious. Are those in Christ no longer responsible for their actions: definitions, interpretations, behaviour? This must be deemed a dead end; surely Paul held his fellow Christians responsible for their way of life. Another Pauline discussion in Romans 7 only makes the confusion worse. He finds a complete stranger in himself, but this time it is not God or Christ but the flesh, the evil desire, or the law, which is operative in him and does all the bad things his real self abhors. Paul's description may carry a deep theological (and anthropological) truth, but again, hermeneutically this is a dead end. As subjects, we are responsible for what we do; neither God nor the devil can take that burden from us - at least not yet, as long as we are differential and relational human beings.

\subsection{Objectivation as subject-making}

Identity is a human construct, but we do not apply it only to human beings. We identify and define objects of the physical world. We form and belong in social groups - families, clans or tribes, social classes, associations, working teams, for example, some of which we furnish with lawful responsibility and call "juridical persons". Such entities are heavily objectivated, i.e., we assume that they too are more or less subjects, have an identifiable inner structure and outward appearance. Some entities are more nebulous but often thought to be subjects, such as nation (in contrast to the more clearly identifiable state), and still others, such as race, are suspected of being unusable ideological constructs which nevertheless may affect our way of constructing social differences.

In addition, we identify and objectivate artefacts, which are inanimate but meaningful products of human culture, and give some of these an official status, by means of copyright legislation for instance. We also grant some cultural products the status and rights of significant others. Works of art and the sacred literature of religions typically belong to this category, and we assume the identity of such products by interpreting them not just as documents (Urkunde) of secondary hermeneutical interest, but as penetrating our primary hermeneutical sphere. The most 
heavily objectivated artefacts thus almost seem to be living creatures who converse with us, yet their identity is vulnerable. Their presumed independent "life" may be short, as that of a mediocre book whose world we enter for a couple of hours and then forget. An artefact may be significant for me and my generation, but is reduced to a document from the past when my generation no longer exists. Religious and some other artefacts, e.g., national emblems, may carry deep symbolical significance and imply an ethical imperative: firstly, that we accept the artefact's claim to our true identity, and secondly, that the artefact be "kept alive", so that necessary reinterpretations are made to ensure its contemporary significance. A religious artefact is binding on us, but it has to be interpreted to suit new life situations, and from time to time it has to be changed. If the imperative is too rigid and unjust, the significant other becomes a tyrant and imposes on us an identity we cannot really accept. Such a relationship is always unhealthy; the bond of love is turned into fear, bitterness and hate. Ultimately, every artefact's identity and survival depends on those who find it significant. As a significant other, a sacred text is like a parent. It nourishes our identity, but in turn, we are obliged to care for its well-being.

\subsection{Meaning, significance, attribution}

In every hermeneutical relation, there are basically two foci (and practically innumerable combinations of such), namely the interpreter and the interpreted object. Meaning is the interpreter's conception of the object's inside sphere of identity, while significance is the interpreter's conception of the relationship between his or her identity and the object's meaning. The difference between meaning and significance thus corresponds to the distinction between secondary and primary hermeneutics. Biblical exegesis is concerned with the meaning of the interpreted texts; biblical hermeneutics is about the significance of these texts for the interpreter.

The borderline between meaning and significance is, of course, just as fluid as that between secondary and primary hermeneutics. The most obvious reference of "meaning" is to human behaviour and artefacts. Thus the two concepts of identity and meaning are interdependent and complementary. Identity is basically the construction of the human (individual and social) symbolic universe, and meaning the construction of the worlds of concrete and artefactual reality as these appear from the viewpoint of the meaning-giving symbolic universe. Thus, human beings do (by behaving and acting in the concrete world) and make (by producing artefacts) "meaningful" things. However, this functional difference between identity and meaning is, in practice, very blurred. The interpreter cannot infer the "meaning" of the object without initially 
"identifying" it - whereby the object at once receives an "identity" with the concomitant duality of inside and outside, which in turn bifurcates "meaning" into meaning and significance.

The process of giving meaning and significance to cultural constructs includes various amounts of conceptual enrichment, where meaningful and significant relations are attributed to interpreted objects as their properties (in the widest sense, i.e., as the sphere of their identity, power and belonging). Concrete, symbolic and artefactual entities and their compounds may thus be enriched by conceiving of their relations with other entities as belonging to them. The four legs belong to the dog. This perception seems quite natural, even though in our earliest experience we attributed our mother's body to ourselves like our fingers and toes. Seemingly as naturally, we attribute other people's bodies, gestures and speech acts to these individuals, and enrich their personhood with their clothing, habits, emotions, values and social roles. A small child is often attributed to the parents, a wife to her husband, a servant to the master of the household. Even that may seem natural enough, but we already recognise the power relations inherent in such attributions.

Power, in this specific sense, is the capacity of an entity to define itself and to be regarded by others as a differential identity, the capacity of an identity to define the identity (or lack of it) of other entities, the capability of an identity to attribute properties to itself and others, and the capability of gaining approval for such attributions. But all power is not the same. An object may attract attributions (significance) that do not correspond to its inner identity: e.g., women may not be content with the attributes given to them by a patriarchal value system. Even when the inner and outer attributions (meaning and significance) match, the question is how the inner identity has been constructed in the first place: supposing that there are happy slaves and voluntary victims, how is it that they have internalised such social roles?

We enrich social and ideological entities variously by attaching meaningful relations to some social constructs more than to others. In extreme cases, we may be willing or forced to offer our individual lives for the well-being of a larger powerful identity, be it family, nation, faith community or something else. Some texts seemingly have extraordinary power, as they are enriched with deep meaning and significance; we may feel that the "meaning of everything", including the meaning of our lives, somehow dwells in a particular body of texts, such as the Bible. In reality, however, the power of texts is a complex issue, because it is also the power of those who define and interpret them. We sometimes speak of "the Bible" as if it were a unified subject with a will of its own. In fact, it, too, is a historical construct, where conflicting voices are heard. Can 
Mosaic law speak for the prophets, or is Paul's voice the same as James's? Do not the many biblical witnesses have the right to speak out their differential, although related identities instead of being reduced to one voice? If the Bible is allowed to speak in many voices, we in fact recognise in it several significant others.

The complex network of significant others frequently produces loyalty conflicts and calls for priority decisions: what is my responsibility for my family, academic or faith community, country, sacred texts and their original authors? To reduce such conflicts, we often assimilate the overlapping identities by constructing larger conglomerates of identities. The two testaments are the one Bible; the Bible and the Apostles' creed indicate the church's identity; my community's identity is found in the church's identity. Such assimilations are not always viable. Early Christians thought of themselves as Jews, yet their ways parted. The Protestant churches thought they were faithful to the common (Catholic) tradition; this assimilation failed too. In Protestant denominations in particular, the empirical church and the Bible are often regarded as different identities, and loyalty towards the Bible is considered primary. Sometimes even the Bible and the Holy Spirit are seen as demanding opposite loyalties, perhaps to the benefit of the living Spirit paradoxically, such a position may be argued for on the basis of biblical proof texts (e.g., John 16:12-15; 2 Cor. 3:6).

We wish to love all identities as ourselves; in practice, we love some neighbours more than others. Conflicts within our nearest loyalty sphere, our family, are the most crucial ones. Thus the word of Jesus on one's ultimate loyalty depicts precisely a family conflict: "I have come to set a man against his father, and a daughter against her mother, and a daughter-in-law against her mother-in-law; and one's foes will be members of one's own household" (Matt. 10:35-36). Often we avoid such conflicts by reducing differences and constructing a common "family identity" to which each member's loyalty is ultimately directed. That, too, is an exercise of power. If there are conflicting voices, any silencing will be an act of subordination.

\subsection{Transcendental identity}

Since we may enrich our identitity by attributing to ourselves symbolic and artistic properties, our identity always transcends our everyday sphere of reality. Transcendental identity in a more pregnant religious sense refers to an artefactual or symbolic object that is given other than profane human attributes and thereby represents the sacred (or in some cases unholy) Other. As a significant Other, such an object becomes a part of our identity as we attribute some of its properties to ourselves. 
Religious attributions are of several kinds, including (on a downward scale of the three-world model) an interpreted master narrative, a system of beliefs, a set of basic values, a symbolic in-group, and a repertoire of behavioural schemes. Of these attributions, the system of beliefs is obviously the most distinctive trait of religious identity, but all these aspects are necessarily present in one way or another. Thus, to identify oneself as a Christian is to adopt and interpret some basic elements of the Christian story, such as the creation, exodus and the Jesus story, as my transcendental story; to believe in God, Christ, and the Holy Spirit; to adhere to some form of Christian ethics; to belong to a group of Christians; and to have certain habits such as going to the Sunday service.

As differential and relational subjects, we are capable of participating in transcendental identities but can never - in this life or this world - be completely absorbed by one such identity. Religion is the most powerful source of transcendence in the human culture, but it is not almighty. If we are Christians, we are so in our individual ways.

\section{Remembrance and transformation - between history and the future}

\subsection{A chain of memory}

One of the constitutive elements of identity is memory. Without memory there is no continuity, and without continuity no attributions are possible. Identity has a history, but history is only available to us as memory: history as written, interpreted, or experienced. Thus, we may define identity as the memory of its attributions.

I have a history: parents, grandparents. Moving backwards, my history soon becomes obscure. My grandparents' grandparents are not a part of my identity. To transcend my individual being, I must look for more symbolic historical lineages. As a Christian I recognise some prominent figures from Finnish church history as my symbolic grandparents; beyond them, perhaps I turn to Martin Luther, then to the well-known representatives of the early Church and possibly even to the patriarchs of ancient Israel. Is this lineage not very confusing and contradictory, or might it be, if I for once should stop to think of it and analyse - dissolve, deconstruct - this chain of affinity? Is the tribal god of Abraham, Israel and Jacob really my God?

I cannot answer that question, since hermeneutics cannot reach out to the dwelling place of gods. I only know that my symbolic lineage is a vital part of my present identity. To be religious in the Christian way, even in 
our secularised world, is to have a Christian symbolic lineage. In its historical aspect, religion is essentially a chain of memory, as the French sociologist Danièle Hervieu-Léger (2000) has recently defined it. ${ }^{9}$ This chain includes parts of my personal memory, but otherwise it is a collective store of individual and social experiences, as these have been selected, interpreted and assimilated to form a compound of narratives, beliefs, values and schemes of behaviour. While the sacred represents the synchronic aspect of transcendental identity, memory expands it diachronically. In a post-modern society, the sacred is increasingly experienced apart from the religious memory. I think, however, that religion is always needed to unite the synchronic and diachronic aspects of transcendence.

\subsection{Symbolic lineage and accountability}

Ethically, the historical aspect of identity involves a responsibility for the symbolic lineage we have appropriated. The past that informs our identity in a significant and positive way is "a usable past", as feminist liberation theologians may call it.10 To be sure, we cannot just "use" history for identity construction, because any significant other will also imply intellectual and moral accountability. Intellectually, there is a truth demand. We cannot freely call any person our physical mother or father. We have a greater freedom to choose our symbolic parents, but there are still limits to what others will find a reasonable lineage. Ethically, we cannot just "use" our parents and friends; they will also "use" us and put moral demands on us.

The wider ethical issue is: "Who are my past neighbours?" What we do or fail to do to our contemporary neighbours is a matter of our choice, but as we include former generations in our identity, we take on their past deeds and failures which we cannot change. If we accept all humankind ("Adam and Eve") and the history of the universe as our symbolic past neighbour, as perhaps we ideally should, our burden ("hereditary sin") becomes overwhelming, while such abstract transcendence may not suffice for our differential identity. In practice, Christians tend to adopt a more limited lineage, but that, too, imposes a huge responsibility. Are we accountable for all that the ancient Israelites, the early Christians, the Reformers, the founding fathers of the community, did to those outside? For how long are we guilty of our symbolic forefathers' sins - until the

9 However, I cannot follow Hervieu-Léger when she tends to view memory and the sacred as alternative rather than complementary approaches to religion.

10 For the distinction between the "usable" and "unusable" past, see Schüssler Fiorenza (1983:16). 
third or fourth generation, or until we have corrected the wrongs that their actions, views and texts cause in our contemporary world?

There is no easy answer, but hermeneutically, at least two approaches seem possible in meeting the ethical challenge. In the secondary hermeneutical direction, we may begin with the supposedly universal Other, i.e., elementary global values to be respected in all history, and then ask how our own tradition complies with such common rules. In that case, we are concerned about the Christian tradition in the widest sense and the global responsiblity it invites us to take. If we begin from the primary hermeneutical sphere, we may examine our own symbolic lineage and ask for more precise ancestoral lines, differences and degrees in our complex belonging-in-the-world, and take responsibility accordingly: as Scandinavian male scholars, as South African feminist theologians, or however we define our true identity. By defining our symbolic lineage more closely, we are, so to speak, able to reduce our inherited guilt.

However, it seems to me both intellectually and morally dubious to define "a usable past" in too selective a way, picking up just the most suitable parts and denying everything else. That would seem like saying to one's parents, "I am your child when it pleases me". The more narrowly we define our lineage, the more deeply concerned we should be about the wrongs that this specific lineage has produced in history. If we admit the Pauline legacy at large as our symbolic heritage, then the "Paul" of the early Christian household-code tradition and the sad effective history of the subordination model should also concern us. If we are children of Moses who liberated his people from Egypt, we should also remember the Old Testament stories (whether true or not, they are part of the symbolic package) about the brutal conquest of the promised land by the same people.

\subsection{The dialectic of change}

Both "global" and "local" approaches are therefore needed in the effort to define ourselves as against and in relation to the Other. The latter approach in particular makes us sensitive to the dialectic of historical change. A religious tradition and the identity to which it contributes are not immutable. The very essence of human identity is its capability of defining and redefining its past in relation to its present experiences and future expectations. As individuals, we change from birth to death. With every new compelling experience we must reconsider our symbolic lineage, so that the attributions we adduce to our identity mould our understanding of the past. 
Historical identities only remain the same through continually renewed remembrance and transformation. This paradox holds true for textual, ideological and social identities as well, although the procedure is still more complex than in the case of individual human beings. Inasmuch as the Bible, the Christian faith and the Church are considered to have a self-understanding, this inside sphere of identity ("meaning") may be thought of as a developing, living entity. The text world of the Bible (which, of course, can be defined in a number of ways) does not alter much; after the canon had been closed, the Bible came to include certain books and exclude others. Nevertheless, with every new reader and interpreter, its significance or "outside" aspect of identity is redetermined and reshaped. Since the self-understanding of a living being is also in part shaped by its recognition of the significance it has for others (I understand myself in new ways after becoming an adult, a parent, a teacher, and so on) the same procedure might be assumed for the Bible.

Several things should be borne in mind if we choose to follow this line of reasoning. Firstly, all artefactual and symbolic entities are historical, not eternal, constructs. If we allow a "life" for such entities, we must recognise that they have come into being in history and are subject to death, too. At its birth, the nearest approximation of the emerging identity of "the Bible" would be the way in which those who contributed to its canonical formation understood it (e.g., Irenaeus' conception of the fourfold Gospel). On the other hand, no biblical writer can be regarded as normative in deciding on the "original meaning" of the Bible; the identity of "the Bible" was established after the biblical documents.

Secondly, as a composite text, the Bible is a very ambiguous artefactual identity. A Gospel text or a letter of Paul would, in principle, be a more natural unit of identity. If we think otherwise, this is due to the fact that "the Bible" as a sacred text has undergone an extraordinary heavy objectivation.

Thirdly, socially determinable identities, such as "the Church", might be more plausible candidates as having a "living" inner identity. Of course, problems arise there, too. Much sophisticated theology and Church politics are needed to define the self-awareness of empirical Christian communitites, and the ideas of an eternal/ pre-existent Church (cf. the Shepherd of Hermas, Vis. II.4) or an "invisible" Church are suspected of being too heavy objectivations. It is even more difficult to define the selfawareness of a composite textual identity. The Bible's artefactual identity may seem seducingly self-evident and firm: once the canonical collection was born, it was possible to determine "what the Bible says" chapter by chapter and verse by verse. An inner identity in the analogy of human 
self-awareness would necessarily involve a symbolic level of "life", of which we might ask, "What does the Bible mean (by what it says)?"

If we accept the notion that "the Bible" is a living entity of which Genesis, the book of Daniel, the Gospel of Matthew and Paul's letter to the Romans are organic parts in the way our hands and feet are parts of our physical body, then such a question can be posed - just as we can ask what the "self" uniting the human body "means" when it says something. Personally, I doubt that we can reasonably pose that question, since it presupposes an unduly heavy conceptual enrichment of a composite text. Thus I suggest that we let other identities have their share in the power of "the Bible". These might include the Church (which historically gave birth to the Bible), the common faith (the ideological criteria used in defining the canonical collection of books, or the supposed apostolic regula fidei), the Holy Spirit (which might be perceived as the "living thing" in the process of interpretation), Jesus Christ (as in Luther's ideological principle of selection, quod Christum agit), or simply God (after all, those who reify "the Bible" usually call it "the word of God"). Not being a theologian, I am not specifically recommending any of these (and there may be many more options), but only wish to point out that choosing "the Bible" as a heavily enriched identity is an ideological choice, and not necessarily the most obvious one. ${ }^{11}$

Inasmuch as we speak of textual and symbolic identities as significant others, as subjects with the power to inform our identity, they inevitably become subject to human change. The Bible can only continue to be a part of its readers' identity by being changed and transformed through new attributions. We remember and find significance in it differently in each new situation, and we also forget such aspects of it that the situation renders irrelevant. Thus, in Second Isaiah, two seemingly contradictory exhortations are found. "Do not remember the former things", says the prophet (Is. 43:18-19). After a little while, the same prophet exhorts: "Remember the past things" (46:9-10). On the one hand, the prophet stresses continuity with Israel's past, but on the other hand, he also introduces discontinuity with the past, thus relativising and reshaping it (Wiley, 1997:72-73). This is how we remember history and the texts from our sacred tradition. Past history in itself - as the sum of occurred events in the concrete reality - does not change; but remembrance, history's significance for us, does and must change.

11 In the discussion following my Potchefstroom paper, the question of whether the Bible may be said to "change" was of major interest. I have elaborated the written text on this issue, but my answer must still seem unsatisfactory to those who would enrich the very concept of "the Bible" and underscore its inside aspect of identity more than I am prepared to do. 


\subsection{Incarnation as a double-edged hermeneutical principle}

The hermeneutical fact that textual and symbolic identities change as significant others, corresponds to the theological notion of incarnation. The word becomes flesh as it transforms and is being transformed by us. However, in an hermeneutical sense, incarnation seems a double-edged concept. "As the rain and the snow come down from heaven and do not return until they have watered the earth, making it blossom and bear fruit, and give seed for sowing and bread to eat, so shall the word which comes from my mouth prevail", says Second Isaiah (Is. 55:10-11) about the divine word. In reality, a shower of rain does not return to heaven but is absorbed by the earth and becomes the life-giving water in living beings. Incarnation in this latter sense is the loss of one identity in favour of other identities. That the word of God returns to heaven after it has accomplished its purpose seems a pars pro toto assimilation of identity: the word of God is part of "God talk", just as a rain shower is part of heavenly waters.

However, there may also be a genuine paradox here, pointing to the dual construction of identity; the inside identity (meaning) seemingly remains intact while the outside (significance for us) is poured out. We are used to thinking of quite ordinary texts in the same fashion: a book "nourishes" its readers but does not thereby "empty" itself. Then incarnation is partial and only applies to the aspect of significance. Physical objects are not so constructed. We cannot eat a piece of bread and have it. Once eaten, it is lost for the benefit of the life it nourishes. But is it a loss? If the purpose of the bread is to give life to others, then the loss of identity is just the other side of being transformed into a larger meaningful identity. If the bread is not eaten, it is wasted and eventually thrown away.

The analogy of bread is also used in the Christian tradition, most notably in connection with the Eucharist, but also in the wider sense that the purpose of human identity is its transformation through participation in a larger identity. At the same time, however, it is presupposed that human identity may survive death. In Mark 8:35, Jesus says: "Whoever would save his or her life will lose it; and whoever loses his life for my sake and the gospel's sake will save it". In the Christian narrative, Jesus is the chief exponent of this paradox. In the Gospel of John (12:24), Jesus assures us: "A grain of wheat remains a solitary grain until it falls into the ground and dies; but if it dies, it bears a rich harvest". This would suggest a complete incarnation. Yet in John, Jesus is also the eternal Word of God who returns to heaven after the completed mission.

What happens to human identities after death is beyond the scope of the present discussion. Nevertheless, there is a broad early-Christian 
tradition that the purpose and meaning of Jesus Christ is his significance for others. It might, then, be suggested that the ultimate purpose and meaning of our identity, as Christians, is our significance for others. On the other hand, the common biblical faith also asserts that Christ continues to be a non-absorbed, individual identity; by the same token, it might be held that Christians, too, should have a lasting personal existence. $12 \mathrm{Be}$ that as it may, the Christian existence transcends the individual life, reaching out towards a larger identity, in the hope of transformation. Change was no cause of fear for early Christians, on the contrary, they were expecting and looking for it.

\subsection{Redeeming memories}

It is not accidental, then, that remembrance in Christian faith centres in the cross. It is the narrative and symbolic site of change and transformational hope; but it is also a concrete site, where Jesus of Nazareth once met his destiny, and where here and now the unjust sufferings that burden us, our sisters and brothers, lie. In itself, the fate of an unjust sufferer offers no hope. It is only the paradox of incarnation, the transformation of Jesus' death into a new identity for others, that can make Christian remembrance a redeeming memory, in other words a current enactment of the past in anticipation of, and most of all in labour for, the longed-for transformation. Suffering is no good thing, it is just suffering, as Flora A. Keshgegian notes. Rather, what can heal us and "re-member" us into a community of hope is the memory of the vindication of that suffering (see Keshgegian, 2000: chapters 5 \& 6).

\section{Bibliography}

BERGER, Klaus. 1988. Hermeneutik des Neuen Testments. Gütersloh : Mohn.

HERVIEU-LÉGER, Danièle. 2000. Religion as a Chain of Memory. Trans. Simon Lee. New Brunswick, N.J .: Rutgers University Press.

KESHGEGIAN, Flora A. 2000.Redeeming Memories: A Theology of Healing and Transformation. Nashville : Abingdon Press.

LANDMESSER, Christof. 1999. Wahrheit als Grundbegriff neutestamentlicher Wissenschaft. WUNT 113. Tübingen : Siebeck.

MATTILA, Talvikki. 1999. Naming the Nameless: Gender and Discipleship in Matthew's Passion Narrative. (In Rhoads, David \& Syreeni, Kari, eds. Characterization in the Gospels: Reconceiving Narrative Criticism. Journal for the Study of the New Testament. Supplement, 184. Sheffield : Sheffield Academic Press. p. 153-179.)

RÄISÄNEN, Heikki. 2000. Beyond New Testament Theology: A Story and a Program. 2nd ed. London : SCM.

12 Theologically, the double-edged concept of incarnation corresponds to the duality of Christus pro nobis (partial incarnation, the "effect" of Christ) and Christus in nobis (complete incarnation, absorption). 
SCHÜSSLER FIORENZA, Elizabeth. 1983. In Memory of Her: A Feminist Theological Reconstruction of Christian Origins. New York : Crossroad.

SYREENI, Kari. 1999. Wonderlands: A Beginner"s Guide to Three Worlds. Svensk Exegetisk Årsbok: 33-46.

SYREENI, Kari. 2000. Review of Landmesser's Wahrheit als Grundbegriff neutestamentlicher Wissenschaft. Journal for Biblical Literature, 119(2):347349.

WILLEY, Patricia Tull. 1997. Remember the Former Things: The Recollection of Previous Texts in Second Isaiah. SBL Diss. 161. Atlanta: Scholars Press.

\section{Key concepts:}

dialectic of historical change

identity

remembrance

transformation

\section{Kernbegrippe:}

dialektiek van historiese verandering

herinnering

identiteit

transformasie 